\title{
FUZZY FMEA APPLICATION TO IDENTIFICATION RISK IN- PROCESS PRODUCTION OF TOYOTA HI-ACE WIRING HARNESS PRODUCT
}

\author{
Sri Lestari, Diah Septiyana*, Winda Yuniawati \\ Department of Industrial Engineering, Universitas Muhammadiyah Tangerang \\ Jalan Perintis Kemerdekaan I Babakan No.33, RT 7/ RW 3, Cikokol, Kec. Tangerang, Kota
}

Tangerang, 15118

\begin{abstract}
In product manufacture, the high failure rate problem of produce product is the number of product defects. Several types of defects have a high enough percentage. To solve this problem, we need to identify the failures and to get the assessment information of the three risk factors. Our research using the traditional FMEA method at the production of Wiring Harness products to shows the current condition of various modes of failure in those areas. This study focuses on implementing fuzzy FMEA to identify the potential risks that may occur along with the assembling of the Wiring Harness process. The fuzzy FMEA approach is preventing product and process problems before they occur, this paper is also expected to result in some mitigation effort that can be applied to improve the Wiring Harness production process. With the Fuzzy FMEA method, we have found the highest FRPN value that shows the highest defect such as damage insulation is 8.5, damage terminal is 8.5, and the damaged part is 8.5 and the highest RPN from the traditional FMEA is damage insulation (324). To solve this problem, we propose to use the fishbone diagram and give suggestions for improvements to the highest failure modes that are damaged insulation.
\end{abstract}

Keywords: FMEA; Fuzzy FMEA; Wiring Harness; Risk; Toyota

\section{Introduction}

Product quality is determined by customer demand. Furthermore, qualities are determined as a distinctive feature, the nature of goods, and the services that can meet the customer expectation (Kotler \& Keller, 2009). However, this quality standard faces serious problems that come from defective products that cause many claims from consumers. If a defective product moves to the consumer and then causes a loss, the company must replace the loss that has been experienced by the consumer. One of the biggest negative effects was the collapse of the company's reputation in the eyes of consumers. If such a situation is not addressed immediately, the company will lose potential customers. Therefore with good and correct quality control, the manufacture of the product can meet consumer desires (Sutiyarno \& Chriswahyudi, 2019). That is why the production process is very important and should be improved continuously in wiring harness car spare part company that located in Balaraja district.

The assembly process uses defective cable products that exceed the minimum limit set by the company, namely 5\%, in February 2018 was $9.19 \%$, March 2018 was 8.15\%, and April 2018 was 8.19\%.

*Correspondence Author

E-mail: dee.septie@gmail.com
So that the number of defects in the assembly of the wiring harness needs to be minimized. One way that can be done in increasing productivity and minimizing the level of disability is to approach FMEA. The main objective of FMEA is to discover and correct the potential failure problems during the stages of production and quality assurance.

There have been many approaches available to identify risk. Failure mode and effect analysis (FMEA) is a method to shows potential failure modes at one level and investigates the effect on the next subsystem level (Sharma et al., 2005). Many studies have been used FMEA approach to identify risk in their case. Budi Puspitasari et al., (2017) using FMEA to improve product quality in Toyota Motor Manufacturing Indonesia. Sukwadi et al., (2017) using FMEA method to determine the risk priority of failure mode in a work accident. Kumru \& Kumru (2013) using fuzzy FMEA to identify potential failures in the purchasing process of a public hospital. Fuzzy FMEA is applied to overcome the limitation of conventional FMEA such as the subjective and qualitative description, in natural language, the relative importance among the risk ratings, the difference of risk representation among the same ratings, and the knowledge shared among FMEA team members (Kumru \& Kumru, 2013). Sharma et al (2005) argue the fuzzy risk assessment methodology based on fuzzy sets theory (propounded by Zadeh (1965) provides a more flexible and meaningful way to assess risk 
associated with component/item failure modes (Sharma et al., 2005).

This study focuses on implementing fuzzy FMEA to identify the potential risks that may occur along with the assembling of the Wiring Harness process. Fuzzy FMEA is adopted to minimize the subjectivity of experts' assessment in the risk factors evaluation stage. There is still no published record that applies the fuzzy FMEA approach for identifying risk in the Wiring Harness production process. It is expected that this study could contribute to share knowledge regarding the risk profile of the Wiring Harness production process. As the purpose of Fuzzy FMEA approach is to prevent product and process problems before they occur, this paper is also expected to result from some mitigation effort that can be applied to improve the Wiring Harness production process. The production company of Wiring Harness product is employed as the case study to implement the fuzzy FMEA methodology.

\section{Methods}

\section{A. Failure mode and effect analysis (FMEA)}

FMEA is an analytical technique that combines the technology and experience of people in identifying foreseeable failure modes of a product or process and planning for its elimination (D. Besterfield, C. Besterfield-M., G.H. Besterfield, 2003). FMEA is one of the tools to help to control the quality of the product would be the Failure Mode and Effect Analysis (FMEA) method. FMEA identifies potential failures by assigning a value or score for each failure mode based on occurrence level, severity level, and detection level (Stamatis, 2005).

The traditional FMEA uses a risk priority number (RPN) to evaluate the risk level of a component or process. The RPN is obtained by finding the multiplication of three factors, which are the probability/ occurrence of the failure $(\mathrm{O})$, the severity of the failure (S), and the probability of not detecting the failure (D) (Kumru \& Kumru, 2013). Traditional FMEA uses a score of 1 and 10 (with 1 being the best and 10 being the worst case) is given for each of the three factors, and a risk-priority-number (RPN). Thus, the RPN value helps the FMEA team to identify the components or subsystems that need priority actions for improvement (Dinmohammadi \& Shafiee, 2013).

Below are the steps taken to implement FMEA:

1. Identifying the production and quality control process in Wiring Harness Product

2. Identifying some potential failure modes of the production and quality control process, the effect of failure modes on the production and quality control, and the cause of the failure modes

3. Assessing failure modes on the machine for severity $(\mathrm{S})$, occurrence $(\mathrm{O})$, and detection (D)

4. Calculating the Risk Priority Number (RPN) (Kumru \& Kumru, 2013)

It can express mathematically such as:

$$
\mathrm{RPN}=\mathrm{O} \times \mathrm{S} \times \mathrm{D}
$$

\section{B. Fuzzy approach to FMEA}

Fuzzy logic is one method to analyze systems that contain uncertainty (Kusumadewi, 2002). Research using Fuzzy Logic will get more accurate results than using conventional FMEA (Immawan et al., 2018). In the Fuzzy FMEA method, the RPN assessment is not carried out as in conventional FMEA but uses fuzzy numbers for the values of S, O, and D which will then be multiplied by the weight of the importance of each of the S, O, and D factors (Mansur \& Ratnasari, 2015). According to (Xu et al., 2002) some weaknesses of Conventional FMEA namely:

1. Statement of the FMEA is often subjective and qualitatively described in natural language.

2. Three levels of severity parameter (S), occurrence (O), and detection (D) are assumed to have similar interests, it turns out in practice the weight of the interests of all three parameters are not the same.

3. The value of risk priority number (RPN) was produced by multiplying the level of $\mathrm{S}, \mathrm{O}$ and $\mathrm{D}$ may imply a representation of risk.

To overcome the weakness - the weakness of the method is based on fuzzy logic is often used to manipulate the linguistic terms used directly in making a critical assessment (Immawan et al., 2018). FMEA fuzzy process stages (Immawan et al., 2018; Mansur \& Ratnasari, 2015):

1. Arrange to fuzzification (Define the fuzzy set membership function for three parameters $S, O, D$ as fuzzy input)

2. Create a rule-based fuzzy logic (By using the IFThen rules obtained from experts and workers. It's combined into a mapping from fuzzy input to fuzzy inference)

3. Defuzzification/ Perform Fuzzy inference process.

The most popular ones among fuzzy logic systems with fuzzy concepts (fuzzy sets, verbal variables, etc.) are the following: pure fuzzy logic systems, Takagi and Sugeno's fuzzy system, and fuzzy logic systems with fuzzifier and defuzzifier (Mariajayaprakash \& Senthilvelan, 2014). One of the most commonly used algorithms in fuzzy logic is the Mamdani algorithm (Rafie \& Samimi Namin, 2015). Three input variables (S, O, D) are made fuzzy using the membership function. As a membership function, trimf was used in this study. Trimf (triangular-shaped membership function) is a function of a vector $\mathrm{x}$ and depends on three scalar parameters ( $a, b$, and c), as given by (Adar et al., 2017):

$$
f(x ; a ; b ; c)=\left\{\begin{array}{cl}
0, & x \leq a \\
\frac{x-a}{b-a}, & a \leq x \leq b \\
\frac{c-x}{c-b}, & b \leq x \leq c
\end{array}\right.
$$

Perform the Fuzzy inference process is Fuzzy logic output can be converted into a real value that represents the risk (RPN value again). 
Table 1. Linguistic, Severity, Occurrence, and Detection Fuzzy Number Detection

\begin{tabular}{ccccc}
\hline No & Severity & Occurrence & Detection & Fuzzy Number \\
\hline 1 & Insignificant & Rare & Almost Certain & $1,2,3,4,5$ \\
2 & Moderate & Possible & Moderate & $4,5,6,7,8$ \\
3 & Catastrophic & Almost Certain & Almost Uncertain & $7,8,9,10$ \\
\hline
\end{tabular}

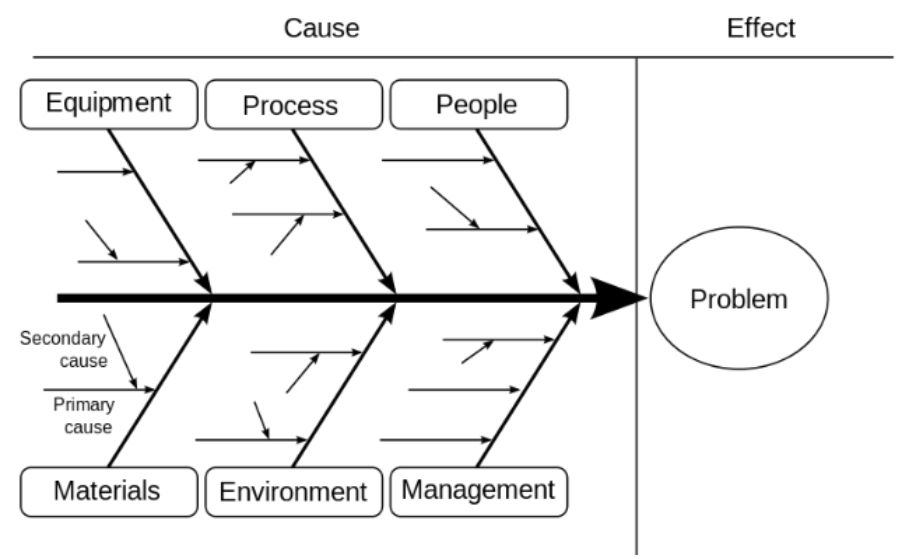

Figure 1. Fishbone Diagram

Table 2. Failure Mode Identification

\begin{tabular}{cll}
\hline No. & Process & \multicolumn{1}{c}{ Potential Failure Mode } \\
\hline 1 & Sub Assy & TPO (Terminal Push Out), cross circuit, wrong cavity, missing spacer/ retainer \\
2 & Setting & Unlock spacer/ retainer \\
3 & Tapping & Loose tapping, loose band clamp, wrong dimension, wrong tapping, wrong part, \\
& missing tapping, missing part, damage terminal, damage insulation \\
5 & Checker & Not click fuse, damage part \\
6 & Finishing & Missing tie back \\
\hline
\end{tabular}

The defuzzification centroid can be determined by the following equations:

$$
\mathrm{y} *=\mathrm{y}_{\mathrm{c}}=\frac{\int \mathrm{y} \mu_{\mathrm{output}}(\mathrm{y}) \mathrm{dy}}{\int \mu(\mathrm{y}) \mathrm{dy}}
$$

Where:

$y^{*}$ - crisp output

$y_{c}$ - center of area(COA)

$\mu$ - member of function

\section{Fishbone Diagram Method}

The Fishbone diagram is often called a Causeand-Effect Diagram or Ishikawa Diagram. Kaoru Ishikawa, a quality control expert from Japan, is one of the seven basic quality tools ( 7 basic quality tools). Fishbone diagrams are used to identify possible causes of problems and especially when a team tends to go into a routine (Tague, 2005). This tool identifies multiple potential factors that cause overall effect problems (Yazdani \& Tavakkoli-Moghaddam, 2012).

In the fishbone diagram each branch represents the "root cause" of the problem is written down or visually by several machine factors (machines or technology), namely methods (methods or processes), materials (including raw materials, consumption, and information), Manpower, Measurement, or inspection), and the Environment.

\section{Result and analysis}

\section{A. Result of FMEA Application}

The result of this study is shown in Table $\mathbf{1}$ and

Table 2 with Figure 1 describing failure mode identification from the wiring harness production process and Table 2 explaining the results of failure modes, effects, and causes of failure mode. Determine risk identification from the process production of wiring harness using method generates risk factor by identifying any potential negative event occurred on a business process. Identification of negative events could be done by determining sub-system failure and risk drivers that cause failures. After determining the value of severity, occurrence, and detection, then we can calculate the value RPN for each of these failure modes.

Based on the FMEA in Table 2, it can be seen the level of risk of each type of failure in each process. Based on Table 3, the failure of the damage insulation results in an RPN value of 324 where the highest value is and requires handling/ repair. This failure has a severity score of 9 which means that a rework process can be carried out in the area/ cage rework, rework on 
Table 3. Failure Modes, Effect, and Cause, Risk Priority Number (RPN)

\begin{tabular}{|c|c|c|c|c|c|c|c|}
\hline $\begin{array}{l}\text { Process } \\
\text { Name }\end{array}$ & $\begin{array}{c}\text { Potential } \\
\text { Failure Mode }\end{array}$ & Potential Effect of Failure & Potential Cause of Failure & $\mathbf{S}$ & $\mathbf{O}$ & D & RPN \\
\hline \multirow{4}{*}{$\begin{array}{c}\text { Sub Assy } \\
/ \\
\text { Housing }\end{array}$} & $\begin{array}{l}\text { TPO } \\
\text { (Terminal } \\
\text { Push Out) }\end{array}$ & $\begin{array}{l}\text { No Current Found when } \\
\text { inspection Process }\end{array}$ & $\begin{array}{l}\text { Operator not using SOP which is } 4 \mathrm{~T} \\
\text { (tekan tarik tekan tarik) }\end{array}$ & 5 & 2 & 3 & 30 \\
\hline & Cross Circuit & $\begin{array}{l}\text { Checking Process stop in the } \\
\text { middle, there is a jumper on } \\
\text { checker machine }\end{array}$ & $\begin{array}{l}\text { The operator does not scan the Kanban } \\
\text { and does not follow the existing } \\
\text { navigation sequence }\end{array}$ & 7 & 7 & 1 & 49 \\
\hline & Wrong Cavity & $\begin{array}{l}\text { Checking Process stop in the } \\
\text { middle, there is a jumper on } \\
\text { checker machine }\end{array}$ & $\begin{array}{l}\text { The operator does not scan the Kanban } \\
\text { and does not follow the existing } \\
\text { navigation sequence }\end{array}$ & 7 & 7 & 1 & 49 \\
\hline & $\begin{array}{l}\text { Missing } \\
\text { Spacer/retainer }\end{array}$ & The connector cannot lock & $\begin{array}{l}\text { There is no sorting of the material when } \\
\text { it is supplied }\end{array}$ & 5 & 2 & 7 & 70 \\
\hline Setting & $\begin{array}{l}\text { Unlock } \\
\text { spacer/retainer }\end{array}$ & $\begin{array}{l}\text { The connector cannot be } \\
\text { attached to the opponent's } \\
\text { connector because the spacer } \\
\text { is blocked }\end{array}$ & $\begin{array}{l}\text { Operators do not follow the existing } \\
\text { standard sequence of processes }\end{array}$ & 4 & 3 & 3 & 36 \\
\hline \multirow{4}{*}{ Tapping } & Loose tapping & Tapping is not tight or loose & $\begin{array}{l}\text { The tapping method was not up to } \\
\text { standard and the fork spacing was too } \\
\text { low causing the tape to hit the jig board }\end{array}$ & 5 & 7 & 4 & 140 \\
\hline & $\begin{array}{l}\text { Loose Band } \\
\text { Clamp }\end{array}$ & $\begin{array}{l}\text { The clamp/clip cannot be } \\
\text { attached to the car body }\end{array}$ & $\begin{array}{l}\text { The operator does not self-check when } \\
\text { cutting the clamp band with a gun }\end{array}$ & 4 & 5 & 6 & 120 \\
\hline & $\begin{array}{l}\text { Wrong } \\
\text { dimension }\end{array}$ & $\begin{array}{l}\text { The size of a certain part } \\
\text { exceeds the tolerance limit } \\
\text { desired by the customer }\end{array}$ & $\begin{array}{l}\text { Lack of production preparation, lack of } \\
\text { approval on the jig board, and the } \\
\text { operator did not include the circuit/ wire } \\
\text { on the fork in the rapping process }\end{array}$ & 7 & 8 & 5 & 280 \\
\hline & Wrong tapping & $\begin{array}{l}\text { The mismatch of the tapping } \\
\text { method between the } \\
\text { specifications and the actual } \\
\text { tapping process results }\end{array}$ & $\begin{array}{l}\text { The operator does not follow a standard } \\
\text { sequence of work processes and the } \\
\text { operator does not understand drawings }\end{array}$ & 6 & 2 & 5 & 60 \\
\hline \multirow{5}{*}{ Tapping } & Wrong part & $\begin{array}{l}\text { The wiring harness cannot } \\
\text { be attached to the car body }\end{array}$ & $\begin{array}{l}\text { Placement of parts or materials that are } \\
\text { not in accordance with the identity of the } \\
\text { material, do not carry out activities } 7 \mathrm{~s}\end{array}$ & 7 & 2 & 4 & 56 \\
\hline & $\begin{array}{l}\text { Missing } \\
\text { Tapping }\end{array}$ & $\begin{array}{l}\text { Wire can be scratched } \\
\text { because it is not protected by } \\
\text { tappings }\end{array}$ & $\begin{array}{l}\text { Operators do not follow existing process } \\
\text { sequences and work standards }\end{array}$ & 6 & 2 & 5 & 60 \\
\hline & Missing part & $\begin{array}{l}\text { The wiring harness cannot } \\
\text { be attached to the car body }\end{array}$ & $\begin{array}{l}\text { Operators do not follow existing process } \\
\text { sequences and work standards }\end{array}$ & 5 & 5 & 2 & 50 \\
\hline & $\begin{array}{l}\text { Damage } \\
\text { terminal }\end{array}$ & $\begin{array}{l}\text { Difficulty when the joining } \\
\text { process is carried out with } \\
\text { the opponent's terminal }\end{array}$ & $\begin{array}{l}\text { During the process, the terminal is not } \\
\text { inserted into the gutter so that it is } \\
\text { trampled on }\end{array}$ & 9 & 3 & 8 & 216 \\
\hline & $\begin{array}{l}\text { Damage } \\
\text { insulation }\end{array}$ & $\begin{array}{l}\text { Cause sparks when the car is } \\
\text { started and cause a fire in the } \\
\text { vehicle }\end{array}$ & $\begin{array}{l}\text { During the process, the circuit is not } \\
\text { inserted into the gutter, so it is stuck with } \\
\text { another part }\end{array}$ & 9 & 6 & 6 & 324 \\
\hline \multirow[b]{2}{*}{ Checker } & $\begin{array}{l}\text { Not click the } \\
\text { fuse }\end{array}$ & $\begin{array}{l}\text { There is no current when } \\
\text { simulating the car }\end{array}$ & $\begin{array}{l}\text { The operator did not perform the SOP } \\
\text { properly }\end{array}$ & 5 & 4 & 2 & 40 \\
\hline & Damage part & $\begin{array}{l}\text { The wiring harness cannot } \\
\text { be properly attached to the } \\
\text { car body }\end{array}$ & Operators are not careful when handling & 9 & 4 & 6 & 216 \\
\hline Visual & $\begin{array}{l}\text { Missing tie } \\
\text { back }\end{array}$ & $\begin{array}{l}\text { Difficult to do the bundling } \\
\text { wiring harness on the box } \\
\text { (not neat) }\end{array}$ & $\begin{array}{l}\text { Operators do not follow existing process } \\
\text { sequences and work standards }\end{array}$ & 4 & 3 & 3 & 36 \\
\hline \multirow[t]{2}{*}{ Finishing } & $\begin{array}{l}\text { Unlock lock } \\
\text { protector }\end{array}$ & $\begin{array}{l}\text { Circuit/wire is not neat and } \\
\text { visible }\end{array}$ & $\begin{array}{l}\text { The operator does not do a self-check } \\
\text { when finished pressing the protective } \\
\text { lock }\end{array}$ & 4 & 9 & 5 & 180 \\
\hline & Exposed wire & $\begin{array}{l}\text { Circuit/ wire can be seen/ } \\
\text { pinched }\end{array}$ & $\begin{array}{l}\text { The operator does not tidy up the circuit/ } \\
\text { wire when installing the protector }\end{array}$ & 5 & 6 & 6 & 180 \\
\hline
\end{tabular}




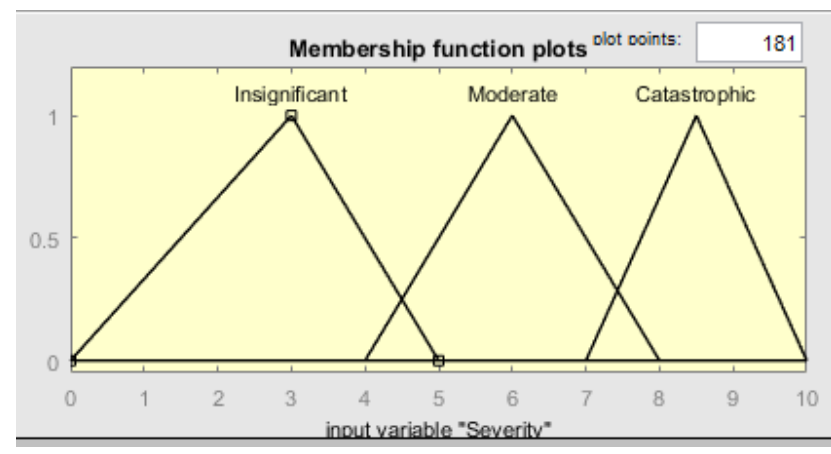

Figure 2. Fuzzy Ratings for Severity Assessment of Failure and Their Membership Function

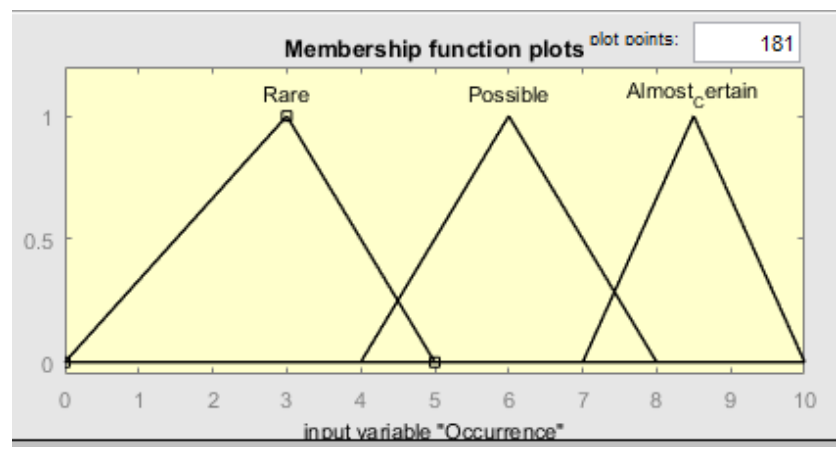

Figure 3. Fuzzy Ratings for Occurrence Assessment of Failure and Their Membership Function

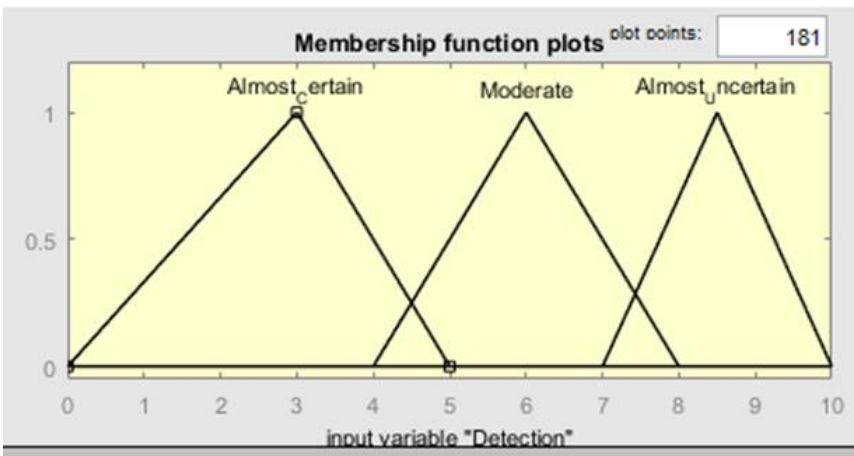

Figure 4. Fuzzy Ratings for Detection Assessment of Failure and Their Membership Function

Table 4. Fuzzy weights for the relative importance of risk factors

\begin{tabular}{cc}
\hline Linguistic & Fuzzy Number \\
\hline Low & $1,2,3,4,5$ \\
Medium & $4,5,6,7,8$ \\
High & $7,8,9,10$ \\
\hline
\end{tabular}

the wiring harness but for the damaged circuit part must be removed and replaced with a new circuit, the occurrence score is 6 , which means that the failure occurs on a moderate level and a detection score of 6 which means that this failure has a low probability of being detected.

\section{B. Result of Fuzzy approach to FMEA}

After carrying out the identification risk that occurs in the Wiring Harness product process (Table 1). Next, determine the priority based on the assessment of risk factors using the conventional FMEA method. These risk factors include the severity $(\mathrm{S})$, the degree of frequent occurrence of risk $(\mathrm{O})$, and whether the risk is easy or difficult to detect (D). Then the risk priority number (RPN) value will be obtained from each risk or mode of failure that occurs (Table 3). In the fuzzy logic using Matlab software program has been used in calculating the value of Fuzzy RPN. The input of fuzzy logic has three variables; Severity, Occurrence, and Detection, and one output variable (FuzzyRPN) (Kumru \& Kumru, 2013).

In this paper, the 3-class evaluation was used, including linguistic variables: low, moderate, and high. Of the three membership functions are then producing 24 fuzzy rules, which are used as a factor determining the value fuzzy RPN. Determining fuzzy numbers of S, O, and D based on Table 3. These linguistic terms are perfectly consistent with those defined by the traditional FMEA, but they are treated as trapezoidal and triangular fuzzy numbers in this paper rather than precise numerical values (Wang et al., 2009). Figures 2-4 show their membership functions for the sake of visualization.

To overcome the result of FMEA's traditional weakness due to no accounts of the relative importance of the risk factors and treats them equally [16]. Hence in this study considered the relative importance weights of the risk factors, but they are not easy to be precisely determined due to the same reason as $\mathrm{S}, \mathrm{O}$, and $\mathrm{D}$. these assessed using the linguistic terms in Table 4, whose membership functions are visualized in Figure 4.

The result of set fuzzy defuzzification was done using Centroid (center of gravity technique) method. In Centroid, the value is obtained based on the gravity of the decision-making process yield curve (Immawan et al., 2018). In this study, defuzzification is used to find the value of output in the form of FRPN value of the input that has been entered. Inputs come from the 
Table 5. Comparison of RPN and Fuzzy RPN

\begin{tabular}{|c|c|c|c|c|c|c|c|c|}
\hline \multirow{2}{*}{$\begin{array}{c}\text { Process } \\
\text { Name }\end{array}$} & \multirow{2}{*}{ Potential Failure Mode } & \multicolumn{3}{|c|}{ Value } & \multicolumn{2}{|c|}{ FMEA Results } & \multicolumn{2}{|c|}{ Fuzzy FMEA results } \\
\hline & & $\mathbf{S}$ & $\mathbf{O}$ & $\bar{D}$ & RPN & Priority & FRPN & Priority \\
\hline Sub Assy & TPO (Terminal Push Out) & 5 & 2 & 3 & 30 & 19 & 6.0 & 16 \\
\hline \multirow[t]{3}{*}{ / Housing } & Cross Circuit & 7 & 7 & 1 & 49 & 14 & 6.0 & 14 \\
\hline & Wrong Cavity & 7 & 7 & 1 & 49 & 15 & 6.0 & 13 \\
\hline & Missing Spacer/ retainer & 5 & 2 & 7 & 70 & 9 & 6.0 & 8 \\
\hline Setting & Unlock spacer/ retainer & 4 & 3 & 3 & 36 & 17 & 2.6 & 18 \\
\hline \multirow[t]{4}{*}{ Tapping } & Loose tapping & 5 & 7 & 4 & 140 & 7 & 6.0 & 6 \\
\hline & Loose Band Clamp & 4 & 5 & 6 & 120 & 8 & 6.0 & 7 \\
\hline & Wrong dimension & 7 & 8 & 5 & 280 & 2 & 5.0 & 17 \\
\hline & Wrong tapping & 6 & 2 & 5 & 60 & 10 & 6.0 & 10 \\
\hline \multirow[t]{5}{*}{ Tapping } & Wrong part & 7 & 2 & 4 & 56 & 12 & 6.0 & 11 \\
\hline & Missing Tapping & 6 & 2 & 5 & 60 & 11 & 6.0 & 9 \\
\hline & Missing part & 5 & 5 & 2 & 50 & 13 & 6.0 & 12 \\
\hline & Damage terminal & 9 & 3 & 8 & 216 & 3 & 8.5 & 2 \\
\hline & Damage insulation & 9 & 6 & 6 & 324 & 1 & 8.5 & 1 \\
\hline \multirow[t]{2}{*}{ Checker } & Not click fuse & 5 & 4 & 2 & 40 & 16 & 6.0 & 15 \\
\hline & Damage part & 9 & 4 & 6 & 216 & 4 & 8.5 & 3 \\
\hline Visual & Missing tie back & 4 & 3 & 3 & 36 & 18 & 2.6 & 19 \\
\hline \multirow[t]{2}{*}{ Shiage } & Unlock lock protector & 4 & 9 & 5 & 180 & 5 & 6.0 & 4 \\
\hline & Exposed wire & 5 & 6 & 6 & 180 & 6 & 6.0 & 5 \\
\hline
\end{tabular}

severity, occurrence, and detection that have been obtained from the results of FMEA risk identification using conventional methods in Table 5.

Based on Table 5 there is a difference between the value and ranking among the RPN and Fuzzy RPN. This is due to calculations using RPN simply done by multiplying the severity, occurrence, and detection alone and irrespective of the degree of importance of each input. While FRPN value obtained from the fuzzification generates value by considering the degree of interest of any given input. In the process of defuzzification, calculations have put the rules that prioritize the handling of the problem over to the cause of the risk. In this study, all the risk factors were based on expert opinion.

\section{Risk Evaluation and Mitigation}

Based on Table 5, that, the value of each FRPN failure mode is sorted, which is the largest FRPN value top rank. FRPN value got the highest priority to low priority. The highest FRPN value that shows the highest defect such as damage insulation is 8.5, damage terminal is 8.5, and the damaged part is 8.5. The highest priority FRPN value same with RPN value is damage insulation in the tapping process. The potential failure of damage insulation got value RPN is 324 and FRPN is 8.5. This research found 19 risks are classified as corrective risks from 7 processes in the production of Wiring Harness.

Damage insulation defects are the largest part that affects the defect rate above 5\%. Damage insulation defect is damaged or scratched to reveal the insulation (copper inside the circuit/ wire). Mitigation efforts are proposed to identify the root cause of the problem using a fishbone diagram. After we finish finding the root cause of the problem, we will be given suggestions for improvement for the failure mode that has the highest FRPN score. Figure 3 shows root cause analysis using a fishbone diagram for damaged insulation. Based on the Fishbone Diagram which can be seen in Figure 5 and the proposed improvements to the failure of damaged insulation can be seen in Table 6.

\section{Conclusion}

This study is applying fuzzy FMEA methodology to identify and evaluate the risk that happens in-process production of Toyota Hi-Ace Wiring Harness Product. To improve the effectiveness of the traditional FMEA, develop a fuzzy-FMEA approach for risk and failure mode analysis in Wiring Harness Product. The fuzzy approach is used the Fuzzy Risk Priority Number (FRPN). The fuzzy FMEA approach is preventing product and process problems before they occur, this paper is also expected to result in some mitigation effort that can be applied to improve the Wiring Harness production process. This study found 19 risks are classified as corrective risks from 7 processes in the production of Wiring Harness. Using the fishbone diagram, we have found the root analysis and then suggest how to solve the problem.

The failure mode such as damage insulation, we suggest providing SWCT (Standard Work Combination Table) training to each operator to better understand the job. We believe it is necessary to 


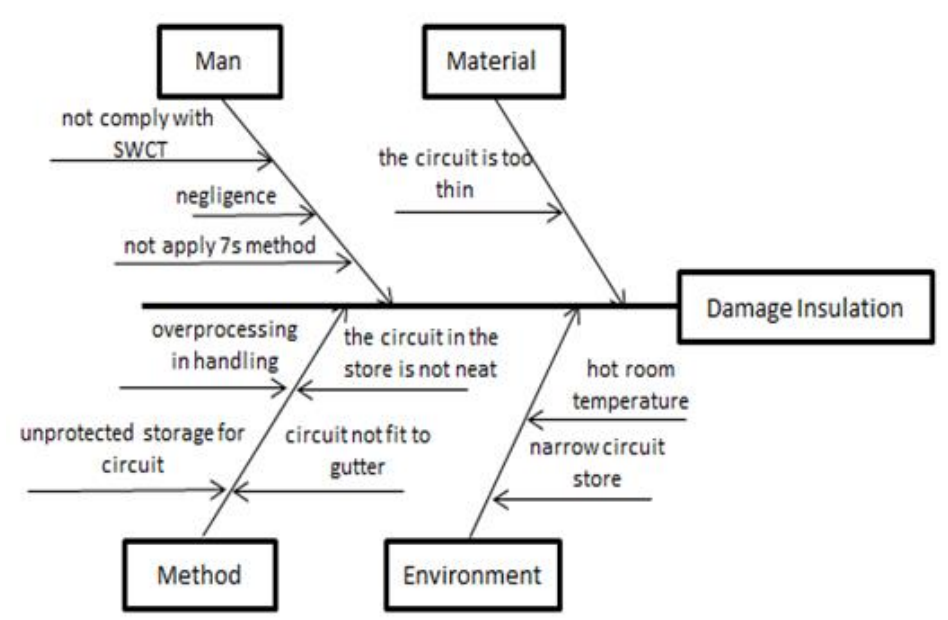

Figure 5. Root Cause Analysis Using Fish Bone Diagram for Damage Insulation

Table. 6. Mitigation Was Proposed Using The Fishbone Diagram

\begin{tabular}{|c|c|c|}
\hline Failure Mode & Factor & Proposed Improvement \\
\hline \multirow{10}{*}{$\begin{array}{l}\text { Damage } \\
\text { Insulation }\end{array}$} & Man & Providing training and supervision to operators, both new employees, and old employees \\
\hline & & Reaffirm the SWCT and 7s method for the tapping part \\
\hline & & Provide sanctions for operators who do not participate in SWCT and $7 \mathrm{~s}$ method \\
\hline & Material & Changing the size of the circuit with a larger diameter than before \\
\hline & Method & Reducing the handling process by reducing the ready-to-hand hanger \\
\hline & & Change the process layout to make it easier to do the hand to hand method \\
\hline & & $\begin{array}{l}\text { Inserting a circuit on the gutter so that it does not hit the floor then you are stepped on or } \\
\text { pinched by the conveyor }\end{array}$ \\
\hline & & $\begin{array}{l}\text { Wrap the end of the terminal with a special plastic so that it is protected and does not } \\
\text { scratch other circuits when placing it in the circuit store }\end{array}$ \\
\hline & Environment & Converting area wider space for the operator when placing the circuit in the circuit store \\
\hline & & $\begin{array}{l}\text { Provide air conditioning such as a blower or fan in the circuit store area so that the operator } \\
\text { does not rush when placing the circuit }\end{array}$ \\
\hline
\end{tabular}

change the layout to facilitate the moving process without hanger, insert a circuit in the gutter so that the circuit is not trampled by the operator or conveyor, and provide air conditioning such as a blower or fan so that the operator does not rush to work.

This study has not calculated the implementation costs from suggestions for future improvements. However, the benefit is to get that can be applied to improve the Wiring Harness production process.

\section{Reference}

Adar, E., Ince, M., Karatop, B., \& Bilgili, M. S. (2017). The risk analysis by failure mode and effect analysis (FMEA) and fuzzy-FMEA of supercritical water gasification system used in the sewage sludge treatment. Journal of Environmental Chemical Engineering, 5(1), 1261-1268. https://doi.org/10.1016/j.jece.2017.02.006

Budi Puspitasari, N., Padma Arianie, G., \& Adi Wicaksono, P. (2017). Analisis identifikasi masalah dengan menggunakan masalah dengan menggunakan metode failure mode and effect analysis (FMEA) dan risk priority number (RPN) pada sub assembly line (Studi Kasus :
PT. Toyota Motor Manufacturing Indonesia). J@ti Undip : Jurnal Teknik Industri, 12(2), 77. https://doi.org/10.14710/jati.12.2.77-84

D. Besterfield, C. Besterfield-M., G.H. Besterfield, M. B.-S. (2003). Total Quality Management. Pearson Education, Inc.,.

Dinmohammadi, F., \& Shafiee, M. (2013). A fuzzyFMEA risk assessment approach for offshore wind turbines. International Journal of Prognostics and Health Management, 4(SPECIAL ISSUE 2), 1-10.

Immawan, T., Sutrisno, W., \& Rachman, A. K. (2018). Operational risk analysis with Fuzzy FMEA (Failure Mode and Effect Analysis) approach (Case study: Optimus Creative Bandung). MATEC Web of Conferences, 154. https://doi.org/10.1051/matecconf/201815401 084

Kotler, P., \& Keller, K. L. (2009). Marketing management (13th ed.). In Prentice Hall.

Kumru, M., \& Kumru, P. Y. (2013). Fuzzy FMEA application to improve purchasing process in a public hospital. Applied Soft Computing Journal, 13(1), 721-733. https://doi.org/10.1016/j.asoc.2012.08.007 
Kusumadewi, S. (2002). Analisis dan Desain Sistem Fuzzy Menggunakan Toolbox Matlab. Graha Ilmu.

Mansur, A., \& Ratnasari, R. (2015). Analisis Risiko Mesin Bagging Scale Dengan Metode Fuzzy Failure Mode and Affact Analysis (FuzzyFmea) Di Area Pengantongan Pupuk Urea Pt. Pupuk Sriwijaja. Teknoin, 21(4). https://doi.org/10.20885/teknoin.vol21.iss4.art 2

Mariajayaprakash, A., \& Senthilvelan, T. (2014). Optimizing Process Parameters of Screw Conveyor (Sugar Mill Boiler) Through Failure Mode and Effect Analysis (FMEA) and Taguchi Method. Journal of Failure Analysis and Prevention. https://doi.org/10.1007/s11668-014-9887-2

Rafie, M., \& Samimi Namin, F. (2015). Prediction of subsidence risk by FMEA using artificial neural network and fuzzy inference system. International Journal of Mining Science and Technology. https://doi.org/10.1016/j.ijmst.2015.05.021

Sharma, R. K., Kumar, D., \& Kumar, P. (2005). Systematic failure mode effect analysis (FMEA) using fuzzy linguistic modelling. International Journal of Quality and Reliability Management, 22(9), 986-1004. https://doi.org/10.1108/02656710510625248

Stamatis, D. H. (2005). Failure Mode and Effect Analysis; FMEA from Theory to Execution (Issue April).

Sukwadi, R., Wenehenubun, F., \& Wenehenubun, T. W. (2017). Pendekatan Fuzzy FMEA dalam
Analisis Faktor Risiko Kecelakaan Kerja. Jurnal Rekayasa Sistem Industri, 6(1), 29. https://doi.org/10.26593/jrsi.v6i1.2425.29-38

Sutiyarno, D., \& Chriswahyudi, C. (2019). Analisis Pengendalian Kualitas dan Pengembangan Produk Wafer Osuka dengan Metode Six Sigma Konsep DMAIC dan Metode Quality Function Deployment di PT. Indosari Mandiri. JIEMS (Journal of Industrial Engineering and Management Systems). https://doi.org/10.30813/jiems.v12i1.1535

Tague, N. (2005). The quality toolbox (2nd ed.). Wisconsin: ASQ Quality Press. http://asq.org/quality-press/displayitem/index.html?item $=\mathrm{H} 1224$

Wang, Y. M., Chin, K. S., Poon, G. K. K., \& Yang, J. B. (2009). Risk evaluation in failure mode and effects analysis using fuzzy weighted geometric mean. Expert Systems with Applications, 36(2 PART 1), 1195-1207. https://doi.org/10.1016/j.eswa.2007.11.028

Xu, K., Tang, L. C., Xie, M., Ho, S. L., \& Zhu, M. L. (2002). Fuzzy assessment of FMEA for engine systems. Reliability Engineering and System Safety. $\quad$ https://doi.org/10.1016/S09518320(01)00101-6

Yazdani, A. A., \& Tavakkoli-Moghaddam, R. (2012). Integration of the fish bone diagram, brainstorming, and AHP method for problem solving and decision making-a case study. International Journal of Advanced Manufacturing Technology. https://doi.org/10.1007/s00170-012-3916-7 